Mareta, H. R., Hardjono, H., \& Agustina, L. S. S. (2020). Dampak pola komunikasi keluarga laissez-faire terhadap kecanduan internet pada remaja di kota Surakarta. Indigenous: Jurnal Ilmiah Psikologi, 5(1).43-52. doi:https://doi.org/10.23917/indigenous.v5i1.8740.

\title{
Dampak Pola Komunikasi Keluarga Laissez-Faire Terhadap Kecanduan Internet Pada Remaja di Kota Surakarta
}

\section{Heppy Ria Mareta ${ }^{1}$, Hardjono Hardjono ${ }^{2}$, Laelatus Syifa Sari Agustina ${ }^{3}$}

Program Studi Psikologi, Fakultas Kedokteran, Universitas Sebelas Maret ${ }^{123}$

heppyriam@gmail.com ${ }^{1}$, hardjonohp@staff.uns.ac.id ${ }^{2}$, laelatussyifa.sa@gmail.com³

\begin{abstract}
Nowadays 73,5\% teenagers in Surakarta uses internet more than 4 hours a day. Internet addiction is influenced by several factors, one of them is the relationship with parents. Family communication pattern is an important part of the relationship between parents and teenagers. Laissez-faire family communication pattern becomes the highest possibility factor of causing internet addiction on teenagers. This study aims to determine the relationship between laissez-faire family communication pattern and internet addiction on teenagers in Surakarta. This study uses quantitative methods. It uses purposive incidental sampling, obtained 185 teenagers in Surakarta by using the scale of Internet Addiction ( $r=$ $0,930)$ and scale of Laissez-faire Family Communication Pattern $(r=0,802)$. The analysis of this study is Pearson's product moments. The result of the analysis shows that the value of $r=0,369$ with $p=0,000$ $(p<0,05)$. This result indicates that there is a significant positive relationship between laissez-faire family communication pattern with internet addiction on teenagers in Surakarta.
\end{abstract}

Keywords: family communication pattern; internet addiction; laissez-faire; teenagers

Abstrak. Sebanyak 73,5\% remaja di Kota Surakarta menggunakan internet lebih dari 4 jam per hari. Kecanduan internet dipengaruhi oleh beberapa faktor, salah satunya adalah hubungan yang terjalin dengan orang tua. Pola komunikasi keluarga menjadi salah satu bagian dari hubungan orang tua dengan anak. Pola komunikasi keluarga laissez-faire memiliki kemungkinan tertinggi dalam menyebabkan anak mengalami kecanduan internet karena anggota keluarganya tidak cukup terlibat dalam percakapan.Penelitian ini bertujuan untuk mengetahui hubungan antara pola komunikasi keluarga laissez-faire dengan kecanduan internet pada remaja. Metode yang digunakan dalam penelitian ini adalah kuantitatif. Teknik sampling dalam penelitian ini adalah purposive incidental sampling, diperoleh 185 remaja di Kota Surakarta. Alat ukur yang digunakan adalah Skala Kecanduan Internet $(r=0,930)$ dan Skala Pola Komunikasi Keluarga laissez-faire $(r=0,802)$. Metode analisis data yang digunakan dalam penelitian ini adalah analisis korelasi Pearson's product moment menggunakan program Statistical Product and Service Solution versi 17.0 for windows. Hasil analisis menunjukkan $r=$ 0,369 dengan nilai $p=0,000(p<0,05)$. Hasil ini menunjukkan bahwa, terdapat hubungan positif yang signifikan antara pola komunikasi keluarga laissez-faire dengan kecanduan internet pada remaja di kota Surakarta.

Katakunci: kecanduan internet; laissez-faire; pola komunikasi keluarga; remaja

\section{PENDAHULUAN}

Hasil survei yang dilakukan oleh Asosiasi Penyelenggara Jasa Internet Indonesia (APJII) pada tahun 2017 menyebutkan bahwa, jumlah pengguna internet di Indonesia mencapai 143,26 juta atau setara dengan 54,68\% dari populasi Indonesia yang berjumlah 262 juta jiwa. Kelompok 
usia 13-18 tahun merupakan pengguna internet tertinggi, yaitu sebesar 75,5\% (APJII, 2017). Kementerian Kominfo melakukan studi yang didanai oleh UNICEF (dalam Broto, 2014) dengan tujuan untuk menelusuri aktivitas online dengan sampel anak dan remaja usia 10-19 tahun (sebanyak 400 responden) yang tersebar di seluruh negeri, baik wilayah perkotaan maupun wilayah perdesaan. Hasil studi tersebut mengatakan bahwa, penggunaan internet di kalangan anak muda Indonesia sudah menjadi satu dengan kehidupan sehari-hari di mana $98 \%$ dari anak-anak dan remaja tahu tentang internet dan 79,5\% merupakan pengguna internet.

Survei awal yang dilakukan oleh peneliti pada bulan Mei 2018 terhadap 34 remaja di kota Surakarta menunjukkan bahwa, 73,5\% remaja menggunakan internet lebih dari 4 jam per hari yang merupakan persentase terbesar. Hampir semua remaja atau $82,4 \%$ remaja pernah merasa berlebihan dalam penggunaan internet. Remaja menggunakan internet paling sering di rumah dibanding tempat lainnya dan layanan internet yang paling sering digunakan adalah media sosial dengan $88,2 \%$. Remaja sering merasa bosan, resah, sepi, dan kurang bahagia ketika sedang offline atau tidak mengakses internet. Hasil lainnya menunjukkan bahwa, 50\% dari remaja tersebut mengabaikan pekerjaan atau tugas lain karena sedang menggunakan internet, 55,9\% remaja menggunakan internet sebagai upaya melarikan diri dari perasaan tidak menyenangkan atau masalah yang sedang dihadapi, dan 76,5\% remaja pernah mencoba untuk mengontrol penggunaan internet.

Kata remaja (adolescence) berasal bahasa Latin, yakni adolescere yang berarti tumbuh ke arah kematangan (Muss, 1968 dalam Sarwono, 2011). Hurlock (1990) mengatakan bahwa, masa remaja merupakan transisi perkembangan yang meliputi sebagian perkembangan kanak-kanak dan sebagian lagi telah mencapai kematangan masa dewasa. Masa remaja disebut sebagai masa penghubung atau masa peralihan antara masa kanak-kanak dengan masa dewasa. Perubahan-perubahan besar dan esensial mengenai kematangan fungsi-fungsi rohaniah dan jasmaniah (khususnya fungsi seksual) terjadi pada periode ini (Kartono, 1995).

Kebutuhan remaja akan internet membuat mereka semakin aktif dalam penggunaan internet. Santrock (2012) mengatakan bahwa, remaja di seluruh dunia semakin bergantung pada internet dan waktu penggunaannya semakin bertambah. Davis (2013) mengungkapkan bahwa, terdapat beberapa fasilitas internet yang dapat memicu timbulnya kecanduan, seperti games, online sex, casino (perjudian), online auctions (lelang) dan stock trading (bursa efek). Jenis-jenis kecanduan internet (Young, Pistner, O’Mara, \& Buchanan, 2000), terdapat lima jenis kecanduan internet, yaitu kecanduan terhadap game, kecanduan terhadap situs web dewasa, kecanduan terhadap media sosial, kecanduan terhadap alat komunikasi, dan kecanduan terhadap situs perjudian atau perdagangan.

Kecanduan internet adalah ketidakmampuan mengontrol diri dalam penggunaan internet yang berlebih sebagai sarana untuk mengabaikan atau melarikan diri dari permasalahan sehingga menimbulkan pikiran-pikiran berlebihan terhadap internet dan mengabaikan kebutuhankebutuhan dasar dalam hidup, seperti mengabaikan pekerjaan dan kehidupan sosialnya (Young, 1996). Penggunaan internet secara berlebih menurut DSM-V mencapai 30 jam per minggu atau 4 sampai 5 jam per hari.

Penggunaan internet menjadi suatu masalah jika telah mengganggu bagian lain dari kehidupan individu, terlebih jika penggunaan internet tersebut telah sampai pada kecanduan. Remaja yang mengalami kecanduan internet akan merasa depresi, cemas, atau hampa saat tidak online di internet (Basri, 2014). Kecanduan internet dapat menimbulkan masalah psikologis, sosial, pendidikan dan pekerjaan serta kesulitan lainnya dalam kehidupan, terutama bagi remaja (Xin, Xing, Pengfei, Houru, Mengcheng, \& Hong, 2017).

Kapahi, Ling, Ramadass dan Abdullah (2015) mengungkapkan beberapa dampak yang 
diakibatkan oleh kecanduan internet melalui penelitiannya di Malaysia, yaitu Insomnia, Perubahan fisik (Physical Change), Inferior (Inferiority), konsentrasi menurun (Loss of Concentration), produktivitas menurun (Loss of Productivity), dan sindrom penarikan diri (Withdrawl Syndrome). Tsitsika, dkk. (2010) juga mengungkapkan kecanduaan internet pada remaja berhubungan dengan beberapa hal, yaitu kinerja akademis yang memburuk, terlibat dalam perilaku berisiko tinggi dan depresi yang meningkat.

Xin, Xing, Pengfei, Houru, Mengcheng, dan Hong (2018) dalam penelitiannya di China juga mengungkapkan bahwa kondisi keluarga tidak hanya menjadi satu-satunya faktor yang memengaruhi kecanduan internet. Faktor lainnya dapat berupa gender dan kondisi di sekolah. Penelitian lain mengenai faktor yang memengaruhi kecanduan internet juga dilakukan oleh Young (2004) serta Kapahi, Ling, Ramadass, dan Abdullah (2013). Hasilnya menunjukkan bahwa kecanduan internet juga dipengaruhi oleh akses internet gratis dan unlimited, banyaknya waktu luang, pengalaman baru tanpa adanya kontrol orang tua, tidak ada monitoring atau pemeriksaan terhadap apa yang dikatakan atau dilakukan ketika online, pengasingan diri dan intimidasi sosial, faktor yang berkaitan dengan tugas, akses yang mudah, akses lokasi yang sesuai untuk pengguna internet, motif dan surfing secara impulsif.

Remaja yang mengalami kecanduan internet dapat diindikasikan dengan adanya masalah dalam hubungan keluarga, hubungan rekan, dan merasa terisolasi dari sosialnya, serta masalah emosional, termasuk gejala depresi (Tsitsika, dkk., 2010). Hubungan yang tidak baik antara remaja dengan orang tua dapat menjadi prediktor kecanduan internet pada remaja di China (Xin, Xing, Pengfei, Houru, Mengcheng, \& Hong, 2017). Salah satu media yang penting dalam hubungan antara anak dan orang tua adalah komunikasi. Komunikasi keluarga yang kurang berkualitas dapat menyebabkan remaja memilih internet sebagai pengganti komunikasi dan dukungan yang tidak didapatkan dari keluarga (Liu, Fang, Deng, \& Zhang, 2012).

Keluarga berperan untuk melakukan tugas-tugas yang menunjang pertumbuhan dan perkembangan yang sehat bagi anggotanya melalui pemenuhan kebutuhan-kebutuhan emosional anggotanya, khususnya remaja (Nasrudin, 2014). Orang tua harus membina komunikasi yang baik dengan anak-anaknya agar tercipta ikatan dan saling membutuhkan. Komunikasi dalam keluarga menjadi bagian penting untuk memprakarsai dan memelihara interaksi antara anggota sehingga tercipta komunikasi yang positif (Wahidah, 2011). Komunikasi yang positif dalam keluarga dilakukan untuk mendorong setiap anggota keluarga agar dapat berkembang secara optimal, baik secara fisik maupun psikis, melalui komunikasi yang responsif, empati, terbuka dan terpercaya, mengandung pesan positif, mendorong optimisme yang proporsional, mendengarkan secara aktif dan tidak menghakimi (Miasari, 2012). Kurangnya komunikasi yang positif dan terbuka dalam keluarga memungkinkan anak mengembangkan perilaku kurang positif (Gulam, 2016).

Kondisi keluarga yang kurang dalam komunikasi, baik kualitas maupun topik pembahasan serta kurang dekatnya hubungan antara keluarga merupakan ciri dari pola komunikasi keluarga laissez-faire (Tajalli \& Zarnaghash, 2016). Pola komunikasi keluarga laissez-faire adalah pola hubungan komunikasi yang ditandai dengan kurangnya percakapan antara anggota keluarga dan interaksi hanya terbatas pada topik tertentu saja (Fitzpatrick \& Koerner, 2002).

Dimensi dari pola komunikasi keluarga laissez-faire adalah orientasi percakapan rendah dan orientasi kepatuhan rendah. Orientasi percakapan yang rendah di dalam keluarga laissezfaire ditandai dengan interaksi tertutup dan terbatas pada pertukaran ide, perasaan dan informasi, serta situasi komunikasi keluarga yang kurang menghargai nilai-nilai percakapan. Interaksi antara anggota keluarga dalam pola komunikasi ini sangat sedikit dan hanya terbatas pada topik tertentu (Fitzpatrick \& Koerner, 2002). 
Orientasi kepatuhan yang rendah di dalam keluarga laissez-faire ditandai dengan interaksi yang terfokus pada perilaku dan kepercayaan yang berbeda, individualitas pada anggota keluarga dan kebebasan dalam dari keluarga mereka. Orang tua membiarkan anaknya untuk membuat keputusan sendiri, tetapi orang tua juga tidak menunjukkan ketertarikan terhadap keputusan yang dibuat oleh anak-anaknya. Pola komunikasi keluarga laissez-faire tidak memiliki kepercayaan terhadap struktur keluarga tradisional. Mereka percaya dalam kebebasan anggota keluarga, ruang nilai pribadi, dan kepentingan pribadi (Fitzpatrck \& Koerner, 2002).

Dari uraian yang telah dikemukakan di atas dapat disimpulkan bahwa, pola komunikasi laissezfaire dalam keluarga kemungkinan berhubungan dengan kecanduan internet pada remaja. Remaja yang memiliki pola komunikasi keluarga laissez-faire kurang memiliki ikatan hubungan yang kuat antara anggota keluarga karena kurangnya percakapan dan kepatuhan. Kondisi ini memungkinkan remaja untuk mencari aktivitas lain berupa penggunaan internet untuk memenuhi kebutuhan dalam lingkungan sosialnya, maka penulis bermaksud meneliti dengan judul: "Hubungan antara Pola Komunikasi Keluarga Laisez-Faire dengan Kecanduan Internet pada Remaja di Kota Surakarta”.

\section{METODE}

Populasi dalam penelitian ini adalah remaja berusia 15 sampai 20 tahun di Kota Surakarta yang berjumlah 47.745 jiwa (BPS, 2016). Penelitian ini menggunakan metode kuantitatif. Teknik pengambilan sampel yang digunakan dalam penelitian ini adalah purposive incidental sampling. Teknik pengambilan sampel yang digunakan pada penelitian ini adalah purposive incidental sampling. Purposive sampling adalah pemilihan responden sebagai anggota sampel atas dasar pertimbangan peneliti sendiri (Darmawan, 2013). Incidental sampling adalah pemilihan sampel berdasarkan individu-individu atau grup-grup yang kebetulan dijumpai atau dapat dijumpai oleh peneliti (Hadi, 2015). Purposive incidental sampling berarti teknik pengambilan sampel berdasarkan kriteria tertentu dan berdasarkan kebetulan yang dijumpai oleh peneliti.

Sampel penelitian yang diperoleh berdasarkan purposive incidental sampling sebanyak 185 remaja. Sampel yang diambil untuk penelitian ini memiliki kriteria, yaitu berusia 15-20 tahun, laki-laki dan perempuan, tinggal bersama orang tua (keduanya atau salah satunya), memiliki akses internet minimal 4 jam per hari, domisili di Surakarta, dan bersedia menjadi subjek penelitian.

Survei pra-penelitian dilakukan untuk mengetahui tingkat kecanduan internet remaja di Kota Surakarta sebagai latar belakang dilakukannya penelitian ini. Survei dilakukan secara online melalui google form pada 34 remaja di Kota Surakarta.

Pengumpulan data dilakukan dengan menggunakan dua skala, yaitu skala kecanduan internet (28 aitem dengan $r=0,930)$ dan skala pola komunikasi keluarga laissez-faire (23 aitem dengan $r=$ 0,802). Skala kecanduan internet dimodifikasi berdasarkan aspek dari Young (1998), yaitu ciri khas, penggunaan yang berlebih, pengabaian pekerjaan, antisipasi, ketidakmampuan dalam mengontrol diri, dan mengabaikan kehidupan sosial. Skala pola komunikasi keluarga laissez-faire disusun berdasarkan dimensi Fitzpatrick dan Koerner (2002), yaitu orientasi percakapan yang rendah dan orientasi kepatuhan yang rendah. Metode analisis data yang digunakan, yaitu uji asumsi dan uji hipotesis dengan menggunakan SPSS 17.0.

Kedua skala tersebut kemudian diujicobakan pada siswa-siswi SMP PGRI 1 Surakarta dan SMK PGRI 2 Surakarta yang memenuhi kriteria sebagai subjek penelitian dengan jumlah 35 responden. Hasilnya menunjukkan daya diskriminasi aitem $\mathrm{r} \geq 0,324$ dengan nilai Alpha Cronbach sebesar 0,930 untuk skala kecanduan internet. Sedangkan, untuk skala pola komunikasi keluarga laissez-faire, didapatkan daya diskriminasi aitem $\mathrm{r} \geq 0,324$ dengan nilai Alpha Cronbach sebesar 
0,802. Hasil tersebut menunjukkan bahwa, kedua skala dapat digunakan dalam penelitian.

Pengumpulan data dalam penelitian ini dilakukan melalui google form pada remaja di 5 kecamatan kota Surakarta dan diperoleh 185 responden. Semua skala yang dijawab dapat diolah dan digunakan sebagai data penelitian.

\section{HASIL DAN PEMBAHASAN}

Tabel 1.

Uji normalitas

\begin{tabular}{lccc}
\hline \multicolumn{1}{c}{ Variabel } & Kolmogorov-Smirnov & sign $(\mathrm{p}>0,05)$ & Keterangan \\
\hline Kecanduan Internet & 1,231 & 0,087 & Normal \\
Pola Komunikasi Keluarga Laissez-Faire & 1,372 & 0,056 & Normal \\
\hline
\end{tabular}

Berdasarkan hasil uji normalitas diperoleh nilai Asymp. Sig. (2-tailed) pada skala kecanduan internet sebesar 0,087 ( $\mathrm{p}>0,05)$ dan nilai Asymp. Sig. (2-tailed) pada skala pola komunikasi keluarga laissez-faire sebesar 0,056 ( $\mathrm{p}>0,05)$. Nilai Asymp. Sig. (2-tailed) pada kedua skala tersebut lebih dari 0,05, sehingga dapat ditarik kesimpulan bahwa, data penelitian pada kedua skala tersebut terdistribusi secara normal.

Tabel 2.

Uji linearitas

\begin{tabular}{ccccc}
\hline Hubungan Variabel & Nilai F & Sig. & $\mathrm{p}$ & Keterangan \\
\hline Pola Komunikasi & 0,86 & 0,042 & $\mathrm{p}<0,05$ & Linear \\
\hline
\end{tabular}

Berdasarkan hasil uji linearitas menunjukkan bahwa, nilai hitung $\mathrm{F}$ sebesar 0,86 dan nilai $\mathrm{F}$ pada tabel adalah 3,893 Nilai F tabel lebih besar dari nilai F hitung $(3,893>0,86)$, sehingga dapat disimpulkan, bahwa kedua variabel tersebut terdapat hubungan linearitas.

Tabel 3.

Uji hipotesis

\begin{tabular}{llc}
\hline & & Pola Komunikasi \\
\hline Kecanduan Internet & Pearson Correlation & $0,069^{* *}$ \\
& Sig. (2-tailed) & 0,000 \\
& $\mathrm{~N}$ & 185 \\
\hline
\end{tabular}

Berdasarkan hasil uji hipotesis ketahui bahwa, nilai korelasi antara variabel pola komunikasi keluarga laissez-faire dengan variabel kecanduan internet adalah 0,369 dengan nilai signifikansi sebesar 0,000 ( $\mathrm{p}<0,05)$. Hasil ini menunjukkan bahwa hipotesis yang diajukan dalam penelitian ini diterima, yaitu terdapat hubungan positif yang signifikan antara pola komunikasi keluarga laissez-faire dengan kecanduan internet pada remaja di kota Surakarta.

Tabel 4.

Sumbangan efektif pola komunikasi keluarga laissez-faire terhadap kecanduan internet

\begin{tabular}{ccccc}
\hline Model & R & R Square & Adjusted R Square & Std. Error of the Estimate \\
\hline 1 & $0,369^{a}$ & 0,136 & 0,131 & 17,905 \\
\hline
\end{tabular}


Berdasarkan hasil perhitungan sumbangan efektf pola komunikasi keluarga laissez-faire terhadap kecanduan internet menunjukkan bahwa, nilai $R$ square yaitu sebesar 0,136 yang berarti bahwa 13,6\% kecanduan internet pada remaja di kota Surakarta dipengaruhi oleh pola komunikasi keluarga laissez-faire. Jadi, dapat dikatakan bahwa persentase sumbangan pengaruh pola komunikasi keluarga laissez-faire terhadap kecanduan internet adalah sebesar 13,6\% dan sisa sebesar $86,4 \%$ dipengaruhi oleh faktor lainnya di luar penelitian ini.

Berdasarkan analisis data, uji hipotesis menggunakan pearson product moment antara pola komunikasi keluarga laissez-faire dengan kecanduan internet didapatkan nilai korelasi (r) sebesar 0,369 dengan nilai signifikansi $0,000(\mathrm{p}<0,05)$. Hasil ini menunjukkan bahwa hipotesis yang diajukan dalam penelitian ini diterima, yaitu terdapat hubungan positif antara pola komunikasi keluarga laissez-faire dengan kecanduan internet pada remaja di kota Surakarta. Selain itu, juga dapat diketahui nilai $r$ adalah positif, hal ini menunjukkan bahwa, arah hubungan antara kedua variabel yang diteliti searah. Artinya, semakin tinggi tingkat pola komunikasi keluarga laissez-faire maka semakin tinggi pula tingkat kecanduan internet pada remaja di kota Surakarta. Sebaliknya, semakin rendah tingkat pola komunikasi keluarga laissez-faire maka semakin rendah pula tingkat kecanduan internet pada remaja di kota Surakarta.

Hal ini sejalan dengan penelitian oleh Tsitsika, dkk. (2010) menunjukkan bahwa, remaja yang mengalami kecanduan internet dapat diindikasikan dengan adanya masalah dalam hubungan keluarga, hubungan rekan, dan merasa terisolasi dari sosialnya, serta masalah emosional, termasuk gejala depresi. Xin, Xing, Pengfei, Houru, Mengcheng, dan Hong (2017) juga mengungkapkan bahwa, hubungan yang tidak baik antara remaja dengan orang tua dapat menjadi prediktor kecanduan internet pada remaja di Chinna. Pengawasan terhadap pemakaian internet yang kurang dari orang tua juga menjadi faktor yang memengaruhi kecanduan internet pada remaja karena remaja merasa lebih leluasa dalam menggunakan internet tanpa adanya keluhan dari orang tua (Young, 2009).

Penelitian lainnya oleh Liu, Fang, Deng, dan Zhang (2012) menunjukkan bahwa, komunikasi keluarga yang kurang berkualitas memungkinkan remaja menggunakan internet sebagai pengganti komunikasi dan dukungan yang tidak didapatkan dari keluarga. Van den Eijinden, dkk. (2010) mengatakan bahwa, orang tua merupakan agen yang penting dan berpengaruh serta praktik pola asuh yang dapat mendorong atau mencegah perilaku dalam penggunaan internet. Keterlibatan remaja dalam hubungan sosial seharusnya menjadi lebih mendalam dan melibatkan emosional lebih intim dibandingkan pada masa kanak-kanak (Oswalt, 2010), akan tetapi pada keluarga dengan pola komunikasi laissez-faire kurang memiliki ikatan emosional yang intim karena anggota keluarga lebih mementingkan kepentingan pribadi sehingga kebutuhan remaja akan hubungan yang intim dengan keluarga tidak dapat terpenuhi. Kurangnya dukungan dan komunikasi dalam keluarga merupakan ciri dari pola komunikasi keluarga laissez-faire (Fitzpatrick \& Koerner, 2002). Penelitian Tajalli dan Zarnaghash (2016) juga menunjukkan bahwa, anak remaja dengan pola komunikasi keluarga laissez-faire memiliki tingkat paling tinggi dalam penggunaan internet daripada pola komunikasi keluarga yang lain.

Selain itu, juga terdapat beberapa analisis tambahan mengenai kecanduan internet berdasarkan jenis kelamin. Hasil tersebut menunjukkan bahwa, tidak ada perbedaan yang signifikan antara kecanduan internet perempuan dengan kecanduan internet laki-laki $(\mathrm{p}=0,781)$. Hasil ini didukung oleh penelitian Dai (2016) dan Tran, dkk. (2017) yang menunjukkan bahwa, tidak ditemukan perbedaan signifikan tingkat kecanduan internet antara laki-laki dan perempuan, meskipun ada kecenderungan bahwa, tingkat kecanduan internet pada perempuan lebih rendah karena perempuan memiliki emosional dan hubungan yang lebih positif dibandingkan laki-laki. 
Analisis tambahan kecanduan internet lainnya berdasarkan usia dimana hasilnya menunjukkan bahwa, terdapat perbedaan yang signifikan antara kecanduan internet pada usia 15 tahun, 16 tahun, 17 tahun, 18 tahun, 19 tahun, dengan 20 tahun ( $\mathrm{p}=0,049)$. Berdasarkan hasil perhitungan mean dapat diketahui, bahwa usia 19 tahun memiliki tingkat kecanduan internet paling tinggi dibanding usia remaja yang lain. Hal ini didukung dengan hasil perhitungan ANOVA yang menyatakan bahwa, terdapat perbedaan yang signifikan pada tingkat kecanduan internet berdasarkan usia. Remaja yang berusia 19 tahun, termasuk dalam kategori remaja akhir. Okwaraji, Aguwa, Onyebueke, ArinzeOnyia, dan Eze (2015) menunjukkan bahwa, remaja akhir memiliki tingkat kecanduan internet lebih tinggi karena pengawasan atau kontrol orang tua cenderung berkurang pada remaja akhir sehingga remaja akhir memiliki kesempatan lebih banyak dalam mengakses internet.

Analisis tambahan lainnya dilakukan terhadap data kecanduan internet berdasarkan tinggal bersama kedua orang tua atau orang tua tunggal. Hasil dari analisis tersebut menunjukkan bahwa, terdapat perbedaan yang signifikan antara kecanduan internet remaja yang tinggal bersama kedua orang tua dengan remaja yang tinggal bersama orang tua tunggal dimana remaja yang tinggal bersama orang tua tunggal memiliki tingkat kecanduan internet yang lebih tinggi $(\mathrm{p}=0,03)$. Orang tua yang berperan sebagai single parent memiliki kewajiban dan tanggung jawab yang lebih banyak sehingga waktu untuk anak pun berkurang. Berkurangnya waktu untuk anak dapat memengaruhi pengawasan dan kontrol orang tua terhadap anak, salah satunya adalah kontrol terhadap pemakaian internet (Fitzpatrick \& Koerner, 2002). Young (2004) mengungkapkan bahwa pengawasan orang tua terhadap pemakaian internet dapat menyebabkan remaja menggunakan internet secara berlebihan hingga menjadi kecanduan.

Berdasarkan analisis tambahan lainnya, didapatkan hasil bahwa, tidak terdapat perbedaan tingkat pola komunikasi keluarga laissez-faire yang signifikan antara subjek yang tinggal bersama kedua orang tua dengan subjek yang tinggal bersama orang tua tunggal $(\mathrm{p}=0,483)$, meskipun ada kecenderungan jika remaja yang tinggal bersama orang tua tunggal memiliki pola komunikasi keluarga laissez-faire yang lebih kuat. Hasil ini didukung dengan penelitian Cherry (2016) yang menunjukkan bahwa, tidak terdapat perbedaan tingkat pola komunikasi keluarga laissez-faire yang signifikan antara subjek yang tinggal bersama kedua orang tua dengan subjek yang tinggal bersama orang tua tunggal karena ada beberapa faktor lainnya yang lebih berpengaruh, seperti karakteristik orang tua dan anak, hubungan antara orang tua dengan anak, serta permasalahan yang terjadi dalam keluarga.

Analisis tambahan lainnya menunjukkan bahwa handphone merupakan perangkat yang paling sering digunakan dalam mengakses internet. Handphone merupakan perangkat yang paling mudah dan praktis untuk dibawa kemana-mana sehingga subjek lebih mudah dalam mengakses internet melalui handphone. Hal ini sejalan dengan survei yang dilakukan oleh APJII (2017) yang menunjukkan bahwa handphone atau smartphone memiliki persentase paling banyak sebagai perangkat yang paling sering digunakan dalam mengakses internet. Penelitian Ben-Yehuda, Greenberg, dan Weinstein (2016) juga menunjukkan hasil bahwa sebagian besar subjek penelitiannya menggunakan smartphone dalam mengakses internet. Smartphone merupakan perangkat yang bisa digunakan dimana saja sehingga remaja dapat mengakses internet kapan saja karena remaja biasanya memiliki koneksi internet pribadi pada smartphone-nya.

Selanjutnya, media sosial menjadi layanan internet yang paling sering digunakan, baik untuk laki-laki maupun perempuan. Perbedaan tinggi juga dapat dilihat dari persentase layanan game online dimana persentase laki-laki lebih tinggi dibandingkan perempuan. Hal ini menunjukkan bahwa subjek laki-laki lebih sering menggunakan layanan internet berupa game online daripada subjek perempuan. Hasil ini didukung dengan penelitian Tran, dkk. (2015) yang menunjukkan 
bahwa, remaja laki-laki lebih sering mengakses game online dan pornografi.

Analisis tambahan selanjutnya dilakukan terhadap tempat dimana subjek sering mengakses internet. Hasil tersebut menunjukkan bahwa sebagian besar subjek menggunakan internet di rumah. Hasil penelitian Wu, dkk. (2016) juga mengungkapkan bahwa, semua subjek penelitiannya memilih rumah sebagai tempat menggunakan internet paling sering.

Rumah menjadi tempat dimana remaja memiliki hubungan dengan keluarganya, termasuk komunikasi. Remaja yang sering mengakses internet di rumah dapat dikatakan bahwa, remaja memiliki waktu luang yang lebih sesuai dengan hasil analisis tambahan pada alasan remaja mengakses internet. Banyaknya waktu luang ketika di rumah dimungkinkan karena kurangnya komunikasi antara anak dengan orang tua. Hal ini sejalan dengan penelitian Liu, Fang, Deng, dan Zhang (2012) sebelumnya yang mengatakan bahwa, komunikasi keluarga yang kurang berkualitas memungkinkan remaja menggunakan internet sebagai pengganti komunikasi dan dukungan yang tidak didapatkan dari keluarga.

Berdasarkan pemaparan hasil analisis dan pembahasan di atas, penelitian ini telah mampu menjawab hipotesis mengenai hubungan pola komunikasi keluarga laissez-faire dengan kecanduan internet pada remaja di kota Surakarta. Namun, penelitian ini tidak terlepas dari keterbatasan-keterbatasan selama proses berjalannya penelitian. Salah satunya adalah populasi yang kurang mencapai proporsi. Populasi penelitian ini adalah remaja Kota Surakarta dengan teknik pengambilan sampel purposive incidental sehingga lebih terfokus pada subjek yang memenuhi kriteria penelitian, bukan para jumlah remaja per kecamatan yang ada di Kota Surakarta.

\section{SIMPULAN}

Hasil analisis data menunjukkan bahwa, terdapat hubungan positif yang signifikan antara pola komunikasi keluarga laissez-faire dengan kecanduan internet pada remaja di kota Surakarta. Semakin kuat pola komunikasi keluarga laissez-faire maka semakin tinggi tingkat kecanduan internet. Sebaliknya, semakin lemah pola komunikasi keluarga laissez-faire maka semakin rendah tingkat kecanduan internet. Pola komunikasi keluarga laissez-faire memengaruhi kecanduan internet pada remaja di Kota Surakarta sebesar 13,6\% dan sisanya sebesar 86,4\% dipengaruhi oleh faktor lain, seperti kebutuhan terkait tugas sekolah, akses internet yang mudah, banyaknya waktu luang dan lain sebagainya.

\section{REFERENSI}

American Psychiatric Association (APA). (2013). Diagnostic and Statistical Manual of Mental Disorders, Fifth Edition. British: Publication Data.

APJII. (2017). Penetrasi dan Perilaku Pengguna Internet Indonesia. Diakses melalui https://web. kominfo.go.id/sites/default/files/Laporan\%20Survei\%20APJII_2017_v1.3.pdf

Badan Pusat Statistik Kota Surakarta. (2016). Penduduk Menurut Kelompok Umur dan Jenis Kelamin di Kota Surakarta. Online. Diakses melalui ttps://surakartakota.bps.go.id/ dynamictable/2018/02/02/38/penduduk-menurut-kelompok-umur-dan-jenis-kelamindi-kota-surakarta.htmlpada 20 April 2018.

Basri, A. S. H. (2014). Kecenderungan Internet Addiction Disorder Mahasiswa Fakultas Dakwah dan Komunikasi ditinjau dari Religiositas. Jurnal Dakwah, XV, (2). 
Broto, G. S. (2014). Siaran Pers. Retrieved from Kominfo.go.id: https://kominfo.go.id/ index.php/content/detail/3834/Siaran+Pers+No.+17-PIHKOMINFO-2-2014+te ntang+Riset+Kominfo+dan+UNICEF+Mengenai+Perilaku+Anak+dan+Remaja+D alam+Menggunakan+Internet+/0/siaran_pers

Ben-Yehuda, L., Greenberg, L., Weinstein, A. (2016). Internet Addiction by Using the SmartphoneRelationships between Internet Addiction, Frequency of Smartphone Use and the State of Mind of Male and Female Students. Journal of Reward Defic Syndr Addict Sci 2 (1): 22-27.

Cherry, J. (2016). The Communication Pattern and Experience of Children in Single Parent Families. Maters Theses \& Specialist Projects. Paper 1595.

Dai, Q. (2016). Gender, Grade, and Personality Differences in Internet Addiction and Positve Psychological Health among Chinese Collage Students. Primary Health Care 6: 248. Doi: 10.4172/2167-1079.1000248.

Darmawan. 2013. Metode Penelitian Kuantitatif. Bandung: Remaja Rosdakarya

Davis, R.A. (2001). A cognitive-behavioral model of pathological Internet use. Computers in Human Behavior, 17, (2), 187-195.

Fitzpatrick, M. A. \& Koerner, A. F. (2002). Chapter 2: Understanding Family Communications Pattern and Family Functions: The Roles of Conversation and Conformity Orientation. Communication Yearbook, 26 (1): 36-68. https://www.apjii.or.id/contenct/read/39/342/ Hasil-Survei-Penetrasi-dan-Perilaku-Pengguna-Internet-Indonesia-2017 pada 15 April 2018.

Hurlock, 2008. Psikologi Perkembangan. Jakarta : Erlangga Press

Hadi, S. 2015. Statistika. Yogyakarta: Pustaka Pelajar

Kapahi, A., Ling, C. S., Ramadass, S., \& Abdullah, N. (2013). Internet Addiction in Malaysia Causes and Effects. Journal iBusiness, 2013, 5: 72-76.

Kartono, K. 1995. Psikologi Anak (Psikologi Perkembangan). Bandung: CV Mandar Maju.

Liu, Q. X., Fang, X. Y., Deng, L. Y., \& Zhang, J. T. (2012). Parent-adolescent Communication, Parental Internet Use and Internet Specific Norms and Pathological Internet Use among Chinese Adolescents. Journal Computer in Human Behavior, 28 (2012): 1269-1275.

Miasari, A. (2012). Hubungan antara Komunikasi Positif dalam Keluarga dengan Asertivitas pada Siswa SMP Negeri 2 Depok Yogyakarta. Jurnal EMPATHY, Vol.I No.1. https:// doi.org/http://journal.uad.ac.id/index.php/ EMPATHY/article/view/ 1411.

Okwaraji, F. E., Aguwa, E. N., Onyebueke, G. C., Arinze-Onyia, A. U., \& Eze, C. S. (2015). Gender, age and class in school differences in internet addiction and psychological distredd among adoledcents in a Nigerian Urban City. International Neuropsychiatric Disease Journal, 4 (3): 123-131. ISSN: 2321-7235.

Oswalt, A. (2010). An Introduction to Adolescent Development. Online. Diakses melalui http:// www.mentalhelp.net/poc/view_doc.php?type=doc\&id=41149\&cn=1310 pada 13 Maret 2018. 
Santrock, J. W. (2012). Life Span Development. Jakarta Timur: Erlangga.

Sarwono. 2011. Psikologi Remaja.Edisi Revisi. Jakarta: Rajawali Pers.

Tajalli, F. \& Zarnaghash, M. (2017). Effect of Family Communication Patterns on Internet Addiction. Journal of Practice in Clinical Psychology, 5 (3): 159-166.

Tran, B. X., Huong, L. T., Hinh, N. D., Nguyen, L. H., Le, B. N., Nong, V. M., dkk. (2017). A study on the influence of internet addiction and online interpersonal influences on healthrelated quality of life in young Vietnamese. BMC Public Health, 17: 138. DOI: 10.1186/ s12889-016-3983-z.

Tsitsika, A., Critselis, E., Louizou, A., Janikian, M., Freskou, A., Marangou, E., Kormas, G. \& Kafetzis, Dimitrios A. (2010). Determinants of Internet Addiction among Adolescents: A Case-Control Study. The Scientific World Journal (2010) 11: 866-874.

Van den Eijnden, R. J. J. M., Spijkerman, R., Vermulst, A. A., Van Rooij, T. J.,\& Engles, R. C. M. E. (2010). Compulsive Internet use among adolescents: Bidirectional parent-child relationships. Journal of Abnormal Child Psychology, 38: 77-89. www.victoriapoint.com/ internetaddiction/internetaddiction.htmpada 15 April 2018.

Wu, C. S. T., Wong, H. T., Yu, K. F., Fok, K. W., Yeung, S.M., Lam, C. H.,dkk. (2016). Parenting approaches, family functionality, and internet addiction among Hong Kong adoscents. BMC Pediatric, 16: 130. DOI: 10.1186/s12887-016-0666-y.

Wahida, S. (2011). Pengaruh dukungan orangtua dan self control terhadap kecenderungan kenakalan remaja SMK Bina Potensi Palu-Sulawesi Tengah. Skripsi. Jakarta: Universitas Islam Negri Syarif Hidayatullah.

Xin, M., Xing, J., Pengfei, W., Houru, L., Mengcheng, W. \& Hong, Z. (2017). Online activities, prevalence of Internet addiction and risk factors related to family and school among adolescents in China. Addictive Behavior Reports, 7 (2018): 14-18.

Young, K. S. (1996). Internet Addiction: The emergence of a new clinic dissorder. Paper presented at the 104th annual meeting of the American Psychological Association, August 11, 1996.

Young, K. S. (2004). Internet Addiction: A New Clinical Phenomenon and Its Consequences. American Behavioral Scientist, 45 (4): 402-415.

Young, K. S. (2009). Internet Addiction: Diagnosis and Treatment Consideration. Journal of Contemporary Psychotheraphy, 39 (4): 241-246.

Young, K., Pistner, M., O’Mara, J., \& Buchanan, J. (2000). CyberDisorders: The Mental Health Concern for the New Millenium. Cyber Psychology \& Behavior. 3 (5), 475-479 
